\title{
Spatial near future modeling of land use and land cover changes in the temperate forests of Mexico
}

\author{
Jesús A Prieto-Amparán ${ }^{1}$, Federico Villarreal-Guerrero ${ }^{1}$, Martin Martínez-Salvador ${ }^{1}$, Carlos Manjarrez- \\ Domínguez $^{2}{ }^{\text {, Griselda Vázquez-Quintero }}{ }^{2}$, Alfredo Pinedo-Alvarez ${ }^{\text {Corresp. } 1}$ \\ 1 Facultad de Zootecnia y Ecología, Universidad Autónoma de Chihuahua, Chihuahua, Chihuahua, Mexico \\ 2 Facultad de Ciencias Agrotecnológicas, Universidad Autónoma de Chihuahua, Chihuahua, Chihuahua, Mexico \\ Corresponding Author: Alfredo Pinedo-Alvarez \\ Email address: apinedo@uach.mx
}

The loss of temperate forests of Mexico has continued in recent decades despite wide recognition of their importance to maintaining biodiversity. This study analyzes land use/land cover change scenarios, using satellite images from the Landsat sensor. Images corresponded to the years 1990, 2005 and 2017. The scenarios were applied for the temperate forests with the aim of getting a better understanding of the patterns in land use/land cover changes. The Support Vector Machine (SVM) multispectral classification technique served to determine the land use/land cover types, which were validated through the Kappa Index. For the simulation of land use/land cover dynamics, a model developed in Dinamica-EGO was used, which uses stochastic models of Markov Chains, Cellular Automata and Weight of Evidences. For the study, a stationary, an optimistic and a pessimistic scenario were proposed. The projections based on the three scenarios were simulated for the year 2050. Five types of land use/land cover were identified and evaluated. They were primary forest, secondary forest, human settlements, areas without vegetation and water bodies. Results from the land use/land cover change analysis show a substantial gain for the secondary forest. The surface area of the primary forest was reduced from $55.8 \%$ in 1990 to $37.7 \%$ in 2017 . Moreover, the three projected scenarios estimate further losses of the surface are for the primary forest, especially under the stationary and pessimistic scenarios. This highlights the importance and probably urgent implementation of conservation and protection measures to preserve these ecosystems and their services. Based on the accuracy obtained and, on the models generated, results from these methodologies can serve as a decision tool to contribute to the sustainable management of the natural resources of a region. 
1 SPATIAL NEAR FUTURE MODELING OF LAND USE AND LAND COVER CHANGES

2 IN THE TEMPERATE FORESTS OF MEXICO

3 Jesús A. Prieto-Amparan ${ }^{1}$, Federico Villarreal-Guerrero ${ }^{1}$, Martin Martínez-Salvador ${ }^{1}$, Carlos

4 Manjarrez-Domínguez ${ }^{2}$, Griselda Vázquez-Quintero ${ }^{2}$, Alfredo Pinedo-Alvarez ${ }^{1}$

$5 \quad{ }^{1}$ Facultad de Zootecnia y Ecología, Universidad Autónoma de Chihuahua, Km 1 Perif. R. Almada, 6 Chihuahua, Chih., 31453, México.

$7 \quad 2$ Facultad de Ciencias Agrotecnológicas, Universidad Autónoma de Chihuahua, Km 1 Perif. R.

8 Almada, Chihuahua, Chih., 31453. México.

9

10 Corresponding Author:

11 Alfredo Pinedo-Alvarez ${ }^{1}$

12 Perif. R. Almada, Chihuahua, Chih., 31453, México.

13 Email address: apinedo@uach.mx 


\section{ABSTRACT}

16 The loss of temperate forests of Mexico has continued in recent decades despite wide recognition

17 of their importance to maintaining biodiversity. This study analyzes land use/land cover change

18 scenarios, using satellite images from the Landsat sensor. Images corresponded to the years 1990,

192005 and 2017. The scenarios were applied for the temperate forests with the aim of getting a

20 better understanding of the patterns in land use/land cover changes. The Support Vector Machine

21 (SVM) multispectral classification technique served to determine the land use/land cover types,

22 which were validated through the Kappa Index. For the simulation of land use/land cover

23 dynamics, a model developed in Dinamica-EGO was used, which uses stochastic models of

24 Markov Chains, Cellular Automata and Weights of Evidence. For the study, a stationary, an

25 optimistic and a pessimistic scenario were proposed. The projections based on the three scenarios

26 were simulated for the year 2050. Five types of land use/land cover were identified and evaluated.

27 They were primary forest, secondary forest, human settlements, areas without vegetation and water

28 bodies. Results from the land use/land cover change analysis show a substantial gain for the

29 secondary forest. The surface area of the primary forest was reduced from $55.8 \%$ in 1990 to $37.7 \%$

30 in 2017. Moreover, the three projected scenarios estimate further losses of the surface are for the

31 primary forest, especially under the stationary and pessimistic scenarios. This highlights the

32 importance and probably urgent implementation of conservation and protection measures to

33 preserve these ecosystems and their services. Based on the accuracy obtained and, on the models

34 generated, results from these methodologies can serve as a decision tool to contribute to the

35 sustainable management of the natural resources of a region. 


\section{INTRODUCTION}

40 Forest ecosystems are important because they provide a wide variety of products and services for

41 the human well being (Hall et al., 2006; Fischer \& Lindenmayer, 2007; Weiskittel et al., 2011)

42 harvested products (Houghton \& Nassikas, 2017), carbon sequestration (Hawkes et al., 2017), soil

43 retention (Borrelli et al., 2017), water supply (Sun et al., 2006) and are the habitat of many species

44 of plants and animals. However, antrophongenic activities are the main cause of degradation of

45 almost half of the world surface in the last three centuries. That has caused the loss of lots of our

46 precious natural resources. Twenty-five nations have practically degraded $100 \%$ of their forests,

47 and another 29 nations have degraded $10 \%$ of their forest areas (Millennium Ecosystem

48 Assessment, 2005).

49 Temperate forests represent a key element in the carbon cycle (Pan et al., 2011). They are

50 important carbon dioxide sinks (Ma et al., 2017), offsetting the emissions produced by the world

51 population (FAO, 2018). Temperate forests store 14\% of the planet's carbon (Pan et al., 2011).

52 However, projections of global environmental change show that temperate forests show high

53 vulnerability (Gonzalez et al., 2010). This vulnerability can change the productivity of forests by

54 modifying net carbon sequestration rates (Peters et al., 2013).

55 Temperate forests of Mexico occupy $17 \%$ of the national territory, represented by 32 millions

56 hectares. In this region, the greatest association of pine and oak forests in the world occurs

57 (González et al., 2012). Around 23 different species of pines and close to 200 species of oaks live

58 in the ecoregion of Sierra Madre Occidental (Navar, 2009). However, 40 thousand hectares of

59 forests get on average lost annually. This region has the highest deforestation rate in the world

60 (Velázquez et al., 2002; Mas et al., 2004). 
61 The study of the land use/land cover changes (LULCC) has become a fundamental research topic,

62 since the change in land use/land cover (LULC) affects forest ecosystems and their biodiversity

63 (Gharun et al., 2017). The LULCC, produced by anthropogenic activities have significantly altered

64 the ecosystems biodiversity and services (Butler \& Laurance, 2008; Miles \& Kapos, 2008;

65 Miranda-Aragón, 2013). The dynamics of LULCC directly affect the landscape patterns, the

66 biogeochemical cycles, the ecosysistems structure and function (Scheffer et al., 2001). Recently,

67 the analysis of the spatio-temporal patterns has been the objective of several research studies

68 (Huang et al., 2009; Manjarrez-Domínguez et al., 2015; Vázquez-Quintero et al., 2016). The

69 models of LULCC commonly employed, quantify deforested surfaces, measuring the degree of

70 change in the ecosystem (Lapola et al., 2011). Regression methods suchs as the logistic regression

71 have been employed to generate models of LULCC. These models suppose that the relationship

72 between the LULCC and the variables that produce it is a logistic function; however, it has been

73 demonstrated that this relationship is too general (Mas, 2010; Mas, 2014). The dynamics and

74 complexity of the ecosystem requires a more complete evaluation of LULCC. The spatial

75 modeling is a technique contemplating alternative scenarios of LULCC, which could contribute to

76 better explain the key processes influencing LULCC (Pijanowski et al., 2002; Eastman et al., 2005;

77 Torrens, 2006; Perez-Vega et al., 2012). Thus, one of the main functions of the LULCC models is

78 the establishment of scenarios, with the aim of changing policies and inadequate practices for the

79 sustainable management of natural resources (DeFries et al., 2007; Berberoğlu et al., 2016).

80 Several approaches to establish LULCC scenarios have been developed and tested to generate

81 scenarios of LULCC. Ferrerira et al. (2012) generated deforestation scenarios to 2050 in the central

82 Brazilian savanna biome finding the possible increase of $13.5 \%$ in deforested areas. Kamusoko et

83 al. (2011) evaluated three scenarios (optimistic, pessimistic and business-as-usual) in the 
84 Luangprabang province, Lao People's Democratic Republic, finding decreases in forest areas in

85 the pessimistic and business-as-usual scenarios and an increase in forest areas in the optimistic 86 scenario under a strict regulatory policy. Gago-Silva et al. (2017) used a combination of Bayesian

87 methods and Weights of Evidence to model the probability of change in a western part of 88 Switzerland. Galford et al. (2015) used Bayesian Weights of Evidence for policiy scenarios from 892010 a 2050 evaluating plans for agriculture and forest in Democratic Republic of Congo.

90 The models to establish reference scenarios of changes in LULCC are based on: systems of 91 equations, statistic models, experts, evolutionary and cellular models, even though there have been 92 efforts to combine plataforms in a multiagent system (Mas et al., 2014; Stan et al., 2017). The statistical models employ spatial statistics and regression, in comparison with the expert models, 94 which allow the expert knowledge to lead the model path (Parker et al., 2003; Soares-Filho et al., 95 2013). The evolutionary or cellular models are very competent to determine the ecologycal 96 alteration; however, they just provide information about the causality or the decision-making 97 (Parker et al., 2003).

98 The generation of LULCC scenarios for the forest region of the state of Chihuahua, Mexico is 99 necessary because of the higher temperate forest deforestation rates in the country. The generation 100 of the LULCC scenario shows two important aspects: expert knowledge and knowledge based on 101 data. Expert knowledge is useful to establish methodological processes according to the needs of 102 the user (Gounaridis et al., 2018). Knowledge based on data, helps to understand the general 103 behavior between the factors of change of land use in a spatial way (Olmedo et al., 2018). Most 104 studies are based on knowledge of the data (Peagelow and Olmedo, 2005; Kityuttachai et al., 105 2013), however, few allow the inclusion of both (Sohares-Filho et al., 2006; Olmedo et al., 2018). 
106 The Dinamica Environment for Geoprocessing Objects (Dinamica-EGO) is a flexible open

107 platform, which allows analyzing distribution, abundance and spatio-temporal dynamic of the

108 landscape (Soares-Filho et al., 2002; Lima et al., 2013). The model incorporated to Dinamica-EGO

109 employs cellular automata to simulate the changes happening in a grid, estimating the transition

110 probability, as well as the direction of changes based in stocastic processes (Rutherford et al., 2008;

111 Arsanjani et al., 2011). Dinamica-EGO allows users to incorporate expert knowledge into the

112 overall statistical analysis based on the spatial data set (Mas et al., 2014). In addition, Dinamica-

113 EGO incorporates the possibility of modifying landscape metrics in the calibration procedure to

114 generate the simulation (Mas et al., 2012). In a comparative evaluation of approaches to modeling

115 LULCC, two key advantages over Dinamica-EGO were emphasized: 1) incorporation of the

116 Patcher and Expander functions. The first function generates new patches in the landscape and the

117 second expands the previously formed patches, 2) Dinamica-EGO allows the incorporation of

118 multiresolution validation by means of the Fuzzy Similarity Index.

119 The aim of the present study was (a) to evaluate the change dynamics in the period from 1990 to

1202017 ; (b) to simulate the changes of LULCC for the year 2050 and (c) to elaborate a discussion

121 about the impacts of different scenarios, which could happen in the future in a forest region of the

122 state of Chihuahua, Mexico. Specifically three scenarios, pessimistic, optimistic and stationary

123 state. The model will identify where the different types fo LULCC could hapen. This will allow

124 that future studies could determine changes in carbon sequestration in both, on the surface

125 extension and quantity.

126 MATERIALS \& METHODS

127 Study area 
128 The study area is located in the western part of the state of Chihuahua, Mexico. It is part of the

129 'Sierra Tarahumara' and have a surface area of 497,159 ha. Its extreme coordinates are $108^{\circ} 00^{\prime}$

$130 \mathrm{~W}, 29^{\circ} 00^{\prime} \mathrm{N}$ and $107^{\circ} 10^{\prime} \mathrm{W}, 27^{\circ} 30^{\prime} \mathrm{N}$ (Figure 1). It is one of the regions of temperate forests,

131 which has experimented the greatest disturbances in the past years in the state of Chihuahua

132 (Herrera, 2002). It belongs to the most extensive forest areas in North America. It is immersed

133 within a complex orography composed of large canyons and deep canyons, which results in a

134 mixture of temperate and tropical ecosystems. It is characterized by its high biodiversity and

135 number of endemic species, estimating the presence of around 4000 species of plants. Also, it is

136 recognized by the International Union for the Conservation of Nature as one of the megacenters

137 of plant diversity (Felger et al., 1995). The main land uses in the area include: pine forests, oak

138 forests, pine-oak and oak-pine forest associations, agriculture and grassland communities. The

139 economic activities in the region are forestry, extensive livestock and rainfed agriculture (INEGI, 140 2003).

141 Figure 1. Location and elevations of the study area.

\section{Data source}

143 For the analysis of the LULCC, three scenes of the Landsat sensor (Path 33, Row 41), with a spatial

144 resolution of $30 \mathrm{~m}$, were used. The scenes corresponded to the years 1990, 2005 and 2017 and they

145 were acquired from clear sky days and each of them taken during the same month to reduce the

146 temporal variation. The scenes were downloaded from the United States Geological Survey

147 (USGS, 2018). The characteristics of each scene can be seen in Table 1.

148 Table 1. Scenes characteristics.

$149 \mathrm{TM}=$ Thematic Mapper, OLI= Operational Land Imager 
150 The scenes were radiometrically corrected. The radiometric correction was carried out with the

151 QGis software v.2.8 through the SemiAutomatic Classification plugin (Congedo, 2013).

152 Integration and composition of bands

153 Once the scenes were corrected, they were integrated into a layer stack. False color composites for

154 the Landsat TM5 were then generated, with a combination of the bands 5, 4 and 3. Band 5

155 corresponds to the infrared channel $(1.55-1.75 \mu \mathrm{m})$, band 4 to the near infrared $(0.76-0.90 \mu \mathrm{m})$ and

156 the band 3 to the red channel $(0.63-0.69 \mu \mathrm{m})$. This combination was applied to the scenes of 1990

157 and 2005. Regarding the scene of 2017, the combination for Landsat OLI8 was applied and

158 corresponded to the bands 6,5 and 4 , where band 6 corresponds to the medium infrared channel

$159(1.55-1.65 \mu \mathrm{m})$, band 5 to the near infrared channel $(0.85-0.88 \mu \mathrm{m})$ and band 4 to the red channel

160 (0.64-0.67mn) (Lillesan and Kiefer, 2000).

161 Land use and land cover classification

162 The Suport Vector Machine (SVM) classification was applied to the 1990, 2005 and 2017 images

163 through the software R (R Core Team, 2016) with the R package "caret" (Kuhn et al., 2018) to

164 obtain LULC information. The SVM classifier is a supervised technique of nonparametric

165 statistical methods (Mountrakis \& Ogle, 2011). The SVM classification has been used in several

166 research studies in the past (Kavzoglu \& Colkesen 2009; Otukei and Blashke 2010; Shao \&

167 Lunetta, 2012). For the supervised classification, five classes of land use were defined; 1) primary

168 forest, 2) secondary forest, 3) human settlements, 4) areas without vegetation and (5) water bodies

169 (Table 2).

170 Table 2. Land use/land cover types determined through the supervised classification method.

171 Modeling and spatial simulation with Dinamica-EGO 
172 The LULCC scenarios were made based on the historical trends of change in forest cover during

173 1990-2017 of the supervised classifications using Dinamica-EGO (Sohares-Filho et al., 2002). The

174 historical trends of LULCC is based on the transition matrix (Monteiro et al., 2018). Dinamica-

175 EGO uses the algorithm of cellular automata, and the method Weights of Evidence (Olmedo et al.,

176 2018). For the simulation of deforestation, the following steps were undertaken: 1) selection of

177 change drivers as well as transitions, 2) exploratory analysis of the drivers of deforestation, 3)

178 simulation and 4) validation. These four steps are described in the following sections.

\section{Selection of variables and transitions}

180 The selection of the set of exploratory variables to simulate the LULCC is essential for the 181 modeling success (Miranda-Aragón et al., 2012; Perez-Vega et al 2016). In this study, 19 variables

182 were used; 17 static and two dynamic variables. Static variables remain constant during model 183 execution. Dynamic variables change during the execution of the model and they are continuously 184 updated in each iteration (Olmedo et al., 2018). The set of variables used is shown in Table 3.

185 Table 3. Variables feeding the deforestation model.

186 The transition refers to the total amount of LULCC that occurred in the simulation period. In this

187 study, the transitions of interest were: a) primary forest to secondary forest, b) primary forest to 188 areas without apparent vegetation, c) primary forest to urban areas and d) secondary forest to areas 189 without apparent vegetation (Table 4).

190 Table 4. Transitions of land use/land cover

\section{Exploratory analysis of the data}

192 When we modeled LULCC dynamics, Weights of Evidence (WoE) were applied to project 193 transition probabilities. Regarding deforestation, degradation or any other type of change, we 194 previously know about the location of favorable conditions for LULCC. The influence of static 
195 and dynamic variables and the elaboration of the LULC maps was performed with WoE in the

196 Dinamica-EGO software (Soares-Filho et al., 2010).

197 Positive values of WoE represent an attraction between a transition of land use and a specific

198 variable. The greater the value of $\mathrm{W}^{+}$, the greater the probability of transition. Negative values of

$199 \mathrm{~W}^{-}$indicate low probabilities of transition instead (Maeda et al., 2010). By using the WoE values

200 of the variables used in the analysis of LULCC, the Dinamica-EGO model calculates the transition

201 probability of each pixel to change. Thus, the pixels are assigned with a probability value for a

202 given transition and probability maps are generated for the transitions of interest (Soares-Filho et

203 al., 2009 and 2010; Mas and Flamenco, 2011).

204 Given that the basic hypothesis of the WoE technique is that the driving variables must be

205 independent, for this study the correlation between the variables was tested through the Cramer

206 Coefficient $(V)$, represented by Equation 2.

$$
V=\sqrt{\frac{\chi^{2}}{\Gamma \ldots M}}
$$

207 Where: $\chi^{2}=$ is the chi-square statistic of the contingency between two variables, $\Gamma=$ denotes the 208 sum of the values of contingency, $M=$ is the minimum of $n-1$ or $m-1$, where $n$ denotes the number 209 of rows and $m$ the number of columns. Bonham-Carter (1994) mentioned that values lower than

2100.5 for the Cramer Coefficient $(V)$ suggest independence, while values higher than 0.5 involve a

211 greater association (Almeida et al., 2003, Teixerira et al., 2009).

\section{Simulation of land use and land cover changes}

213 Three types of scenarios were used for 2050; they were called pessimistic, optimistic and 214 stationary. For the three scenarios, the modeling base was the period 1990-2017. The transition 215 matrix of 1990 and 2017 were used to estimate the possible change in forestry coverage in the 216 future, taking 2017 as the beginning year and 2050 as the final year. In the pessimistic scenario, 
217 the transition probability matrix and the change function (patcher and expander) were modified,

218 increasing the deforestation and fragmentation rates between 1990 and 2017. This was done based

219 on the hypothesis that the development of road infrastructure, urban expansion, fires, uncontrolled

220 exploitation, among others, will produce strong spatial changes of land use. For the optimistic

221 scenario, the state and national forest development plans were considered. Such plans promote the

222 protection and conservation of forest resources (CONAFOR, 2001). For this scenario, the

223 conservation and promotion of strategies to protect forests were represented by reducing the

224 transition matrix value, as well as the patcher and expander change functions. Regarding the

225 stationary scenario, transitions or change functions were not modified. In this case, it is assumed

226 that the trend will be the same as the one between 1990 and 2017.

227 Validation

228 To evaluate the model performance, we used a Fuzzy Similarity Index (FSI), where the 229 representation of a pixel is influenced by itself and its neighborhood (Ximenes et al 2011; Yanai 230 et al., 2011; Chadid et al., 2015). The FSI employed in this study was developed by Hagen (2003), 231 modified by Soares-Filho (2014) and implemented in Dinamica-EGO. The FSI verifies the 232 agreement between the observed and the simulated land use and land cover datasets by obtaining 233 the number of coincident cells within increasing window sizes of a neighborhood (Costanza 1989;

234 Soares-Filho, 2017). The validation process was carried out by comparing a simulated map and a 235 reference map. The simulation of the 2017 LULCC map was generated. To generate the simulation 236 of 2017, the transition matrix was used between 1990 and 2005. The comparison through the FSI

237 allowed to evaluate the areas of coincidence of change and no change between the real and 238 simulated map of 2017. Finally, the general procedure used in this study is outlined in the flowchart 239 depicted in Figure 2. 
240 Figure 2. Flowchart of the methodological procedure followed to produce the proposed scenarios.

241 Abbreviations: TM: Tematic Mapper, OLI: Operational Land Imager, WoE: Weights of Evidence,

242 LUCC: Land use and cover change.

243

244 RESULTS

245 Detection of land use/land cover changes

246 Results from the analysis of LULCC show a considerable gain for secondary forest. The forest

247 cover of the primary forest was reduced from $55.8 \%$ of the study area in 1990 to $37.7 \%$ in 2017 .

248 The areas without vegetation increased their area from 4.11\% to 4.87\% during 1990-2017 (Table

249 5). Regarding human settlements and water bodies, they showed a positive trend with an increase 250 from $0.03 \%$ and 0.01 in 1990 to $0.1 \%$ and 0.03 in 2017 , respectively. In general, the primary forest

251 was the land use that experimented a negative trend. The rest of the land uses showed surface

252 gains. The rate of change obtained indicate that the secondary forest, the human settlements and

253 the water bodies were the land uses with the greatest transformation rates, with 8.03, 12.58 and

25427.48 , respectively, for the period of 1990-2017 and with 10.68, 15.96 and 12.3, respectively, from

2552005 to 2017. Figure 3 shows the area occupied by the land uses studied. Likewise, it shows the

256 rate of change of these land use/land cover for the periods 1990-2005 and 2005-2017. The

257 calculated global precision, based on the Kappa Index, presented values of $80 \%, 85 \%$ and $84 \%$ for

258 1990, 2005 and 2017, respectively.

259 Table 5. Area occupied for five types of land uses during 1990, 2005 and 2017, and rate of change

260 for the periods 1990-2005 and 2005-2017.

261 Table 6 shows the land use/land cover change dynamics. The primary forest lost the greatest

262 surface area (28,406 ha) during 1990-2005, increasing the surface lost to 63,546 ha during 2005-

263 2017. In contrast, the secondary forest showed the largest increases in area with 87,800 ha in the 264 period 1990-2017. 
265

266

267

268

269

270

271

272

273

274

275

276

277

278

279

280

281

282

283

284

285

286

287

288

289

Figure 3. Land use/land cover of 1990 (a), 2005 (b), 2017 (c), changes during 1990-2005 (d) and changes during 2005-2017. Abbreviations: AWV: areas without vegetation, SF: secondary forest, WB: water bodies, HS: human settlements and PF: primary forest.

Table 6. Land use/land cover change dynamics

\section{Transition matrix}

The transition probabilities of LULCC for the periods 1990-2005 and 2005-2017 are shown in Table 7. The diagonal of the matrix represents the permanence probability, i.e. the probability of a LULC type to remain unchanged. The areas without vegetation showed a $90 \%$ probability of transition from 1990 to 2005 , lowering it to $62 \%$ from 2005 to 2017 . The areas of primary forest presented a negative trend with a $71 \%$ probability of permanence in the period 1990 to 2005 , and changing it to $61 \%$ for the period $2005-2017$.

Table 7. Transition matrix of probability for land use/land cover change (1990-2005, 2005-2017, 1990-2017).

\section{Weights of evidence (WoE) analysis}

The WoE of the 19 variables were analyzed to eliminate those values that were above 0.5 , based on the Cramer Coefficient $(V)$. The distance to urban locations showed positive values of $\mathrm{WoE}$ from 1000 to $9000 \mathrm{~m}$ distance and from 42,000 to $47,000 \mathrm{~m}$ indicating an influence for cover change from secondary forest to area without vegetation. The distance to rural localities showed positive values of $\mathrm{WoE}$ in distances from 0 to $700 \mathrm{~m}$. The topographic position index showed positive values in the ranges of -150 to -60 and 120 to 240 . The distance to sawmills indicates that deforestation appears from 0 to $16,000 \mathrm{~m}$ with respect to the process of change between secondary forest to areas without vegetation. The transition from primary forest to area without vegetation is likely to occur in distances to the main roads between 13,000 and $21,000 \mathrm{~m}$. The density of main streams such as rivers and creeks had an influence in densities from 0.039 to $0.079 \mathrm{~m}^{2} / \mathrm{km}^{2}$. 
290 In the transition from primary forest to secondary forest, the variable altitude showed positive

291 values of WoE in the range of 1,200-1,300 m, suggesting that most of the changes occur in this

292 range. The slope showed that the process of change between primary forest and secondary forest

293 is located on slopes of 45-60 and 60-75 degrees. The transition from primary forest to human

294 settlements was influenced by the distance to secondary streams from 500 to 1000 meters. The

295 distance to sawmills presented an influence from 0 to 6,000 meters. The distance to mines showed

296 that the attraction to change occurs between 2000 and $10,000 \mathrm{~m}$.

\section{Model validation}

298 The model validation was carried with the simulated and the true land use classification of 2017.

299 The FSI was applied for neighborhoods from 1 x 1 to 7 x 7 pixels. The minimum value reported

300 for FSI was $49 \%$ in $1 \times 1$ pixels, while in $7 \times 7$ pixels the value of FSI was $91 \%$. These results indicate

301 that the real and simulated land use changes agree from $49 \%$ to $91 \%$. Simulation starts with $49 \%$

302 and adjusts to $91 \%$, reaching a similarity adjustment value at a distance of $210 \mathrm{~m}$. These results

303 agree with that obtained by Ximenes et al. (2011). According to Soares-Filho (2017), and similar

304 studies (Carlson et al., 2012; de Rezende et al., 2015; Elz et al., 2015), for the resolution and the

305 number of transitions considered in the model, the values obtained for the FSI suggest that the

306 models are good and can be used in the simulation of LULCC scenarios. Figure 4 represents the

307 FSI in relation to the size of the window.

308 Figure 4. Variation of the FSI as a function of different distance.

\section{Scenarios}

311 The LULCC based on the transitions between 1990 and 2017 for the stationary, optimistic and 312 pessimistic scenarios are presented in Table 8. 
313 Table 8. Percentage of surface area occupied by five land use/land cover types and rate of change

314 for 2017-2050 based on three scenarios.

315 Figure 5 shows the LULC classification of 2017 and the stationary, optimistic and pessimistic

316 scenarios for 2050 , after the model calibration.

317 Figure 5. a) Land use/land cover of 2017 and simulated land use/land cover projected for the year 3182050 as a result of the b) Stationary, c) Pessimistic and d) Optimistic scenarios. Abbreviations:

319 AWV: areas without vegetation, SF: secondary forest, WB: water bodies, HS: human settlements 320 and PF: primary forest.

321

322 In the stationary scenario the area without vegetation would increase from $4.8 \%$ in 2017 to $5.27 \%$.

323 Likewise, the secondary forest would increase from $57.7 \%$ (2017) to $73 \%$. For this scenario, the

324 changes in human settlement and water bodies would not increase or reduce their area. Conversely,

325 the rate of change of primary forest and secondary forest were the greatest between 2017 and 2050.

326 Regarding the optimistic scenario, it showed reductions in areas of primary forest; however, in

327 lower magnitudes than for the stationary and pessimistic scenarios. For the pessimistic scenario,

328 the Markov matrix was modified considering a greater pressure on the forest ecosystem. The area

329 without vegetation showed a positive trend, with $4.8 \%$ in 2017 and an increase to almost $8 \%$ in

3302050 . The secondary forest would go from $57.7 \%$ to $85.6 \%$ in 2050 . Finally, the primary forest

331 would reduce its area to a $8 \%$ and isolated forest areas would appear. The rate of change for this

332 scenario were the ones that showed the highest values. The LULCC dynamics projected for 2050

333 for the three scenarios (stationary, optimistic, pessimistic) is presented in Table 9.

334 Table 9. Land use/land cover change dynamics (ha) under three projected scenarios.

\section{DISCUSSION}

336 In this study, scenarios of LULCC for 2017 and 2050 were generated for a temperate forest region

337 of Chihuahua Mexico. The scenarios were developed in Dinamica-EGO. Results were consistent 
338 with the results described by Maeda et al. (2011). For the generation of transitions and simulation

339 of scenarios, LULC of 1990, 2005 and 2017 were determined. In general, proximity to sources

340 with anthropogenic activity as well as topography were important factors influencing the change

341 in forest cover. The exchange between primary forest and secondary forest represented the main

342 transition between 1990 and 2017. This transition produced the greatest impact, in agreement with

343 the results reported by Perez-Vega et al. (2016). Such transition was influenced by the altitude,

344 slope, and density of water streams, in agreement with the results of Armenteras et al. (2006) and

345 Chadid et al. (2015). The transition from primary to secondary forest could be attributed to the

346 reduction in pine vegetation, where shrubs would become dominant. A consequence of the

347 reduction of primary forest is the migration of fauna, which deals with the dispersal of the seeds

348 of large-crowned trees (Lehouck et al., 2009). Other consequences include the change of lands to

349 livestock production systems (Maeda et al., 2010) and the presence of areas with high solar

350 incidence and low coverage, which are prone to fires (de Rezende et al., 2015). Another reason for

351 the reduction of primary forest is the proximity to urban rural localities and roads, which is in

352 agreement with the results reported by Aguiar et al. (2007) and Osorio et al. (2015). The proximity

353 to urban and rural communities indicates the possible extraction of wood for export and also

354 facilitates the expansion of the agricultural or grazing frontier (Chadid et al., 2015). This can be

355 verified by the number of sawmills in the study area. The process of deforestation/degradation is

356 strongly related to this cause. In the forested areas of Chihuahua, the rural localities are in a high

357 degree of marginalization (González et al., 2012) where there exist agricultural incentives PEF

3582025 (CONAFOR, 2001), causing the possible increase of the areas without vegetation. Another

359 reason for the degradation may be the distance to the main roads and the topographic position. 
360 The results obtained for the different scenarios showed differences among the surfaces of land use.

361 The stationary scenario resulted in a considerable change in the primary forest, mainly. This

362 scenario considers that the transition values among land use coverages will continue. The long-

363 term impacts of the deforestation/degradation process include increased reservoir sedimentation

364 and decreased flows in the dry season (Gingrich, 1993). Although the optimistic scenario showed

365 increases in non-forested areas, this scenario was the one that showed the greatest resistance fo the

366 transitions from primary forest to any other LULC. This scenario considers the strict application

367 of the regulation of forest resources, in agreement with the general trend in the protection of forest

368 ecosystems to degradation (UN, 2015) and the projections of the PEF 2025 (PEF, 2001). The

369 pessimistic scenario showed the greatest losses in the coverage of the primary forest. In addition,

370 the increase in areas without vegetation, which is mainly associated to cropping and the proximity

371 to water currents, is one of the main outputs of the pessimistic scenario, which agrees with the

372 study by Elz et al. (2015). The increase in agricultural areas resulting from this scenario may

373 benefit the inhabitants economically; however, the expansion of this type of land use/land cover

374 could lead to a greater demand of water for irrigation purposes, which could potentially impact

375 water resources (Maeda et al., 2010).

376 Population growth (Barni et al., 2015), the market demand and the lack of technification for wood

377 processing cause the opening of land and the extraction of wood for self-consumption. Taking

378 these aspects into account, the simulation of changes in forest cover indicates pressure on forest

379 resources, which is consistent with that found by Kamusko et al., (2011). As a consequence, forest

380 degradation could lead to soil loss (Quan et al., 2011), loss in biodiversity (Falcucci et al., 2007)

381 and landscape connectivity (Tambosi et al., 2014), habitat fragmentation (Nagendra et al., 2004),

382 the presence of invasive species (Mas et al., 2012), among others. 
383 The LULCC model of this study incorporated the Markov chains, Cellular Automata and WoE

384 methods. Several transitions were simulated as in the studies by Soares-Filho et al., (2010),

385 Ferreira et al. (2013) and Elz et al. (2015). The validation was carried out based on the FSI, as it

386 was also performed in previous research (Ximenes et al., 2011). The result of this analysis, where

387 the three aforementioned methods are combined, highlighted the variables driving the process of

388 degradation/deforestation, as well as the manipulation based on the knowledge of the transition

389 probabilities, being more suitable for the simulation of LULCC (Mas \& Flamenco, 2011). The

390 transition probability matrices revealed that the primary forest has a negative trend in its occupied

391 area, suggestsing that degradation will continue over this land use, this area of primary forest

392 changed to secondary forest. Although the other transitions did not produce important changes in

393 the spatial configuration of the landscape, but their cumulative long-term effect could negatively

394 impact the functioning of the ecosystems and their biodiversity (Pompa, 2008).

395 In this study, we focused on hypothetical scenarios where the pressure of forest resources was

396 controlled by changing the transition probability. However, it is necessary to study scenarios where

397 market demand (Merry et al., 2009) or illegal timber extraction (Chadid et al., 2015) is considered.

398 The wood clandestinage corresponds to $30 \%$ in the some forest management units of Chihuahua

399 (Silva, 2009).

400 The scenarios are not exact projections of the future state of the environment (Feng and Liu, 2016).

401 However, it is an alternative means of supporting forest managers, which can serve as a valuable

402 tool for studying political decisions (Kolb and Galicia, 2018). That would lead to a better

403 knowledge of forest exploitation and protection. Managers can take into account the proposed

404 scenarios and take decisions based on the one with the most promising results. 
405 Due to the distribution of economic information (municipality based) and the lack of information

406 from georeferenced illicit extractions, we believe an approach such as agent-based models would

407 help to improve the study and address these issues. Finally, the model did not consider climatic

408 variations such as precipitation and temperature, which can affect patterns and dynamics in

409 recovery zones. That should be implemented in future studies.

\section{CONCLUSIONS}

411 The use of scenarios as a methodology to study LULCC has been studied in depth at different

412 scales and in different areas. However, several improvements can be implemented. This study

413 presents an approach that integrates expert knowledge, and geospatial technologies such as

414 geographic information systems and spatial simulation. The developed scenarios were based on

415 the application of the forestry law (non-spatially) as well as the state of the landscape, and not only

416 on the extrapolation of past trends. In addition, the scenarios are spatially explicit, which allow

417 identifying the spatial pattern of change and the possible critical areas of change in forest cover.

418 Finally, this study contributes to the understanding of the future fragmentation of the forest cover.

419 Therefore, the current decisions in the field of forest management and land use/land cover

420 influence the future of our forests and can probably be represented in one of the three proposed 421 scenarios.

\section{REFERENCES}

423 Aguiar APD, Câmara G, Escada, MIS. 2007. Spatial statistical analysis of land-use determinants 424 in the Brazilian Amazonia: Exploring intra-regional heterogeneity. Ecological modelling 209(2425 4):169-188 DOI https://doi.org/10.1016/j.ecolmodel.2007.06.019.

426 Almeida CM, Batty M, Monteiro AMV, Camara G, Soares-Filho BS, Cerqueira GC, Pennachin, 427 CL. 2003. Stochastic cellular automata modelling of urban land use dynamics: Empirical 428 development and estimation. Computers, Environment and Urban Systems 27:481-509 DOI 429 https://doi.org/10.1016/S0198-9715(02)00042-X. 
430 Armenteras D, Rudas G, Rodriguez N, Sua S, Romero M. 2006. Patterns and causes of 431 deforestation in the Colombian Amazon. Ecological Indicators 6(2):353-368 DOI 432 https://doi.org/10.1016/j.ecolind.2005.03.014.

433 Arsanjani JJ, Helbich M, Kainz W, Boloorani AD. 2013. Integration of logistic regression, Markov 434 chain and cellular automata models to simulate urban expansion. International Journal of Applied 435 Earth Observation and Geoinformation, 21: 265-275 DOI 436 https://doi.org/10.1016/j.jag.2011.12.014.

437 Barni PE, Fearnside, PM, de Alencastro Graça PML. 2015. Simulating deforestation and carbon 438 loss in Amazonia: impacts in Brazil's Roraima state from reconstructing Highway BR-319 439 (Manaus-Porto Velho). Environmental management, 55(2: 259-278 DOI 440 https://doi.org/10.1007/s00267-014-0408-6.

441 Berberoğlu, S, Akın, A, Clarke, KC. 2016. Cellular automata modeling approaches to forecast 442 urban growth for adana, Turkey: A comparative approach. Landscape and Urban Planning 153: 443 11-27 DOI https://doi.org/10.1016/j.landurbplan.2016.04.017.

444 Bonham-Carter G. 1994. Geographic Information Systems for Geoscientists: Modelling with GIS. 445 New York: Pergamon.

446 Borrelli P, Robinson DA, Fleischer LR, Lugato E, Ballabio C, Alewell C, Meusburger K, 447 Modungo S, Schütt B, FerroV, Bagarello V, Oost K, Montanarella L, Panagos P. 2017. An 448 assessment of the global impact of 21 st century land use change on soil erosion. Nature 449

450 Butler, RA, Laurance WF. 2008. New strategies for conserving tropical forests. Trends in Ecology 451 \& Evolution 23:469-472 DOI https://doi.org/10.1016/j.tree.2008.05.006.

452 Carlson KM, Curran LM, Ratnasari D, Pittman AM, Soares-Filho, BS, Asner GP, Lawrence D, 453 Rodrigues HO. 2012. Committed carbon emissions, deforestation, and community land conversion 454 from oil palm plantation expansion in West Kalimantan, Indonesia. Proceedings of the National 455 Academy of Sciences 109(19): 7559-7564 DOI https://doi.org/10.1073/pnas.1200452109.

456 Chadid MA, Dávalos LM, Molina J, Armenteras D. 2015. A Bayesian spatial model highlights 457 distinct dynamics in deforestation from coca and pastures in an Andean biodiversity 458 hotspot. Forests 6(11): 3828-3846 DOI doi:10.3390/f6113828

459 Cominsión Naciaonl Forestal (CONAFOR). 2001. Programa Estratégico Forestal 2025. Available 460 at http://www.conafor.gob.mx:8080/documentos/ver.aspx?articulo=307\&grupo=4.

461 Congedo, L. 2017. Semi-Automatic Classification Plugin for QGIS, Technical Report, Sapienza

462 University, ACC Dar Project: Rome, Italy. Available at $463 \mathrm{https} / /$ media.readthedocs.org/pdf/semiautomaticclassificationmanual-

464 v3/latest/semiautomaticclassificationmanual-v3.pdf

465 Costanza R. 1989. Model goodness of fit: a multiple resolution procedure. Ecological Modelling 466 47: 199-215 DOI https://doi.org/10.1016/0304-3800(89)90001-X.

467 de Rezende CL, Uezu A, Scarano FR, Araujo DSD. 2015. Atlantic Forest spontaneous 468 regeneration at landscape scale. Biodiversity and conservation 24(9): 2255-2272 DOI 469 https://doi.org/10.1007/s10531-015-0980-y. 
470 DeFries R, Hansen A, Turner BL, Reid, R, Liu J. 2007. Land use change around protected areas: 471 management to balance human needs and ecological function. Ecological Applications 17(4): 472 1031-1038 DOI https://doi.org/10.1890/05-1111.

473 Eastman JR, Solorzano LA, Van Fossen ME. 2005. Transition potential modeling for land-cover 474 change In: GIS, spatial analysis, and modeling, eds. Maguire D Batty JM, Goodchild MF. ESRI 475 Press, California.

476 Elz I, Tansey K, Page SE, Trivedi M. 2015. Modelling deforestation and land cover transitions of 477 tropical peatlands in Sumatra, Indonesia using remote sensed land cover data sets. Land 4(3): 670478687 DOI 10.3390/land4030670.

479 Falcucci A, Maiorano L, Boitani L. 2007. Changes in land-use/land-cover patterns in Italy and 480 their implications for biodiversity conservation. Landscape ecology 22(4): 617-631 DOI 481 https://doi.org/10.1007/s10980-006-9056-4.

482 FAO, 2018: The state of world's forests 2018 - Forest pathways to sustainable development. FAO, 483 Rome. Available at http://www.fao.org/publications/sofo/en/ (Accessed 7 October 2018).

484 Felger R S, Wilson MF 1995. Northern Sierra Madre Occidental and its Apachian outliers: a 485 neglected center of biodiversity. Biodiversity and Management of the Madrean Archipelago: The 486 Sky Islands of Southwestern United States and Northwestern Mexico, 36-51.

487 Ferreira ME, Ferreira Jr LG, Miziara, F, Soares-Filho, BS. 2013. Modeling landscape dynamics in 488 the central Brazilian savanna biome: future scenarios and perspectives for conservation. Journal 489 of Land Use Science 8(4): 403-421 DOI https://doi.org/10.1080/1747423X.2012.675363.

490 Fischer J, Lindenmayer DB. 2007. Landscape modification and habitat fragmentation: a 491 synthesis. Global ecology and biogeography 16(3): 265-280 DOI https://doi.org/10.1111/j.1466492 8238.2007.00287.x.

493 Gago-Silva A, Ray N, Lehmann A. 2017. Spatial Dynamic Modelling of Future Scenarios of Land 494 Use Change in Vaud and Valais, Western Switzerland. ISPRS International Journal of Geo495 Information 6:115 DOI: 10.3390/ijgi6040115.

496 Galford GL, Soares-Filho BS, Sonter LJ, Laporte, N. 2015. Will passive protection save Congo 497 forests?. PloS one, 10: e0128473 DOI https://doi.org/10.1371/journal.pone.0128473.

498 Gharun M, Possell M, Bell TL, Adams MA. 2017. Optimisation of fuel reduction burning regimes 499 for carbon, water and vegetation outcomes. Journal of environmental management 203:157-170 500 DOI: ttps://doi.org/10.1016/j.jenvman.2017.07.056.

501 Gingrich RW. 1993. The political ecology of deforestation in the Sierra Madre Occidental of 502 Chihuahua (Master's thesis, University of Arizona).

503 González BA. 2012. La Sierra Tarahumara, el bosque y los pueblos originarios: estudio de caso 504 de Chihuahua México. Available at: http://www.fao.org/forestry/17194505 0381f923a6bc236aa91ecf614d92e12e0.pdf

506 Gonzalez P, Neilson RP, Lenihan JM, Drapek RJ. 2010. Global patterns in the vulnerability of 507 ecosystems to vegetation shifts due to climate change. Global Ecology and Biogeography 19:755508768 DOI https://doi.org/10.1111/j.1466-8238.2010.00558.x. 
509 Gounaridis D, Chorianopoulos I, Koukoulas, S. 2018. Exploring prospective urban growth trends 510 under different economic outlooks and land-use planning scenarios: the case of Athens. Applied 511 Geography 90:134-144 DOI https://doi.org/10.1016/j.apgeog.2017.12.001.

512 Hall RJ, Skakun RS, Arsenault EJ, Case BS. 2006. Modeling forest stand structure attributes using 513 Landsat ETM+ data: Application to mapping of aboveground biomass and stand volume. Forest 514 ecology and management 225(1-3): 378-390 DOI https://doi.org/10.1016/j.foreco.2006.01.014

515 Hawkes CV, Waring BG, Rocca JD, Kivlin SN. 2017. Historical climate controls soil respiration 516 responses to current soil moisture. Proceedings of the National Academy of Sciences 114:6322517 6327 DOI: https://doi.org/10.1073/pnas.1620811114.

518 Herrera A. 2002. Situación actual de los bosques de Chihuahua. Madera y bosques 8(1) DOI 519 http://dx.doi.org/10.21829/myb.2002.811302.

520 Houghton RA, Nassikas, AA. 2017. Global and regional fluxes of carbon from land use and land 521 cover change 1850-2015. Global Biogeochemical Cycles 31:456-472 DOI 522 https://doi.org/10.1002/2016GB005546.

523 Huang B, Zhang L, Wu B. 2009. Spatiotemporal analysis of rural-urban land 524 conversion. International Journal of Geographical Information Science 23(3): 379-398 DOI 525 https://doi.org/10.1080/13658810802119685.

526 Instituto Nacional de Estadística, Geografía e Informática (INEGI). 2003. Síntesis de Información 527 Geográfica del Estado de Chihuahua.

528 Kamusoko C, Oono K, Nakazawa A, Wada Y, Nakada R, Hosokawa T, Someya T. 2011. Spatial 529 simulation modelling of future forest cover change scenarios in Luangprabang province, Lao PDR. 530 Forests 2(3): 707-729 DOI 10.3390/f2030707.

531 Kavzoglu, T, Colkesen I. 2009. A kernel functions analysis for support vector machines for land 532 cover classification. International Journal of Applied Earth Observation and 533 Geoinformation, 11(5): 352-359 DOI https://doi.org/10.1016/j.jag.2009.06.002.

534 Kityuttachai K, Tripathi, NK, Tipdecho T, Shrestha R. 2013. CA-Markov analysis of constrained 535 coastal urban growth modeling: Hua Hin seaside city, Thailand. Sustainability 5(4): 1480-1500 536 DOI https://doi.org/10.3390/su5041480.

537 Kuhn M, Wing J, Weston S. 2015. Package 'caret'. Classification and regression training.

538 Lapola D, Schaldach MR, Alcamo J, Bondeau A, Msangi S, Priess JA, Soares-Filho BS. 2011. 539 Impacts of climate change and the end of deforestation on land use in the Brazilian Legal 540 Amazon. Earth Interactions. 15:1-29 DOI https://doi.org/10.1175/2010EI333.1.

541 Lehouck V, Spanhove T, Colson L, Adringa-Davis A, Cordeiro NJ, Lens L. 2009. Habitat 542 disturbance reduces seed dispersal of a forest interior tree in a fragmented African cloud forest. 543 Oikos 118(7): 1023-1034 DOI https://doi.org/10.1111/j.1600-0706.2009.17300.x.

544 Lillesand TM, Kiefer RW. Remote Sensing and Image Interpretation, 4th ed.; John Wiley and 545 Sons: New York, NY, USA, 2000.

546 Lima, T C, Guilen-Lima CM, Oliveira MS, Soares-Filho B. 2013. DINAMICA EGO e Land 547 Change Modeler para simulação de desmatamento na Amazônia brasileira: análise comparativa. 548 In: Anais XVI Simpósio Brasileiro de Sensoriamento Remoto: Foz do Iguaçu, INPE, 6379-6386. 
549 Ma W, Jia G, Zhang A. 2017. Multiple satellite-based analysis reveals complex climate effects of 550 temperate forests and related energy budget. Journal of Geophysical Research: Atmospheres, 551 122(7): 3806-3820 DOI https://doi.org/10.1002/2016JD026278.

552 Maeda EE, Clark B, Pellikka P, Siljander M. 2010. Driving forces of land-use change in the Taita 553 Hills, Kenya. In: 13th AGILE International Conference on Geographic Information Science, 2-5.

554 Maeda EE, Clark BJF, Pellikka P, Siljander M. 2010. Modelling agricultural expansion in Kenya's 555 eastern arc mountains biodiversity hotspot. Agricultural. Systems 103: 609-620 DOI 556 https://doi.org/10.1016/j.agsy.2010.07.004.

557 Maeda EE, De Almeida C M, de Carvalho Ximenes A, Formaggio AR, Shimabukuro YE, Pellikka 558 P. 2011. Dynamic modeling of forest conversion: Simulation of past and future scenarios of rural 559 activities expansion in the fringes of the Xingu National Park, Brazilian Amazon. International 560 Journal of Applied Earth Observation and Geoinformation 13(3): 435-446 DOI 561 https://doi.org/10.1016/j.jag.2010.09.008.

562 Manjarrez-Dominguez C, Pinedo-Alvarez A, Pinedo-Alvarez C, Villarreal-Guerrero F, Cortes563 Palacios L. 2015. Vegetation landscape analysis due to land use changes on arid lands. Polish 564 Journal of Ecology 63: 167-174 DOI https://doi.org/10.3161/15052249PJE2015.63.2.001.

565 Mas J, Kolb M, Houet T, Paegelow M, Olmedo MC. 2010. Una comparación de diferentes 566 enfoques de modelación de cambios de cobertura/uso del suelo. In: Proceedings of the XIV 567 Simposio Internacional SELPER 2010.

568 Mas JF, Flamenco A. 2011. Modelación de los cambios de coberturas/uso del suelo en una región 569 tropical de México. GeoTrópico 5(1): 1-24 DOI http://dx.doi.org/10.5154/r.rchscfa.2014.10.049.

570 Mas JF, Kolb M, Paegelow M, Olmedo MTC, Houet T. 2014. Inductive pattern-based land 571 use/cover change models: A comparison of four software packages. Environmental Modelling \& 572 Software 51: 94-111 DOI https://doi.org/10.1016/j.envsoft.2013.09.010.

573 Mas JF, Pérez-Vega A, Clarke KC. 2012. Assessing simulated land use/cover maps using 574 similarity and fragmentation indices. Ecological Complexity 11: 38-45 DOI 575 https://doi.org/10.1016/j.ecocom.2012.01.004.

576 Mas JF, Velázquez A, Díaz-Gallegos JR, Mayorga-Saucedo R, Alcántara C, Bocco G, Castro R, 577 Fernandez T, Pérez-Vega A. 2004. Assessing land use/cover changes: a nationwide multidate 578 spatial database for Mexico. International Journal of Applied Earth Observation and 579 Geoinformation 5(4): 249-261 DOI https://doi.org/10.1016/j.jag.2004.06.002.

580 Merry F, Soares-Filho BS, Nepstad D, Aamacher G, Rodrigues H. 2009. Balancing, conservation 581 and economic sustainability: the future of the amazon timber industry. Environmental 582 Management EUA 44(3): 395-407 DOI https://doi.org/10.1007/s00267-009-9337-1.

583 Miles L, Kapos V. 2008. Reducing greenhouse gas emissions from deforestation and forest 584 degradation: global land-use implications. Science 320(5882): $1454-1455$ DOI $58510.1126 /$ science. 1155358.

586 Millennium Ecosystem Assessment. 2005. Ecosystems and Human Well-Being: Synthesis. Island 587 Press, Washington, DC.

588 Miranda-Aragón L, Treviño-Garza EJ, Jiménez-Pérez J, Aguirre-Calderón OA, González-Tagle 589 MA, Pompa-García M, Aguirre-Salado CA. 2012. Modeling susceptibility to deforestation of 
590 remaining ecosystems in North Central Mexico with logistic regression. Journal of forestry 591 research 23(3): 345-354 DOI https://doi.org/10.1007/s11676-012-0230-z.

592 Monteiro Junior JJ, Silva E., De Amorim Reis AL, Mesquita Souza Santos, JP. 2018. Dynamical 593 spatial modeling to simulate the forest scenario in Brazilian dry forest landscapes. Geology, 594 Ecology, and Landscapes, 1:7 DOI https://doi.org/10.1080/24749508.2018.1481658.

595 Mountrakis G, Im J, Ogole C. 2006. Support vector machines in remote sensing: A review. ISPRS 596 J. Photogramm. Remote Sens. 2011, 66, 247-259 DOI 597 https://doi.org/10.1016/j.isprsjprs.2010.11.001

598 Nagendra H, Munroe DK, Southworth J. 2004. From pattern to process: landscape fragmentation 599 and the analysis of land use/land cover change. Agriculture, Ecosystems \& Environment 101(2): 600 111-115 DOI https://doi.org/10.1016/j.agee.2003.09.003

601 Navar J. 2009. Allometric equations for tree species and carbon stocks for forests of northwestern 602 Mexico. Forest ecology and Management 257(2) 427-434 DOI 603 https://doi.org/10.1016/j.agee.2003.09.003.

604 Olmedo MTC, Paegelow M, Mas JF, Escobar F. 2018. Geomatic Approaches for Modeling Land 605 Change Scenarios. Switzerland: Springer.

606 Osorio LP, Mas JF, Guerra F, Maass M. 2015. Análisis y modelación de los procesos de 607 deforestación: un caso de estudio en la cuenca del río Coyuquilla, Guerrero, 608 México. Investigaciones geográficas (88): 60-74 DOI http://dx.doi.org/10.14350/rig.43853.

609 Otukei JR, Blaschke T. 2010. Land cover change assessment using decision trees, support vector 610 machines and maximum likelihood classification algorithms. International Journal of Applied 611 Earth Observation and Geoinformation 12: S27-S31 DOI 612 https://doi.org/10.1016/j.jag.2009.11.002

613 Paegelow M, Olmedo, MTC. 2005. Possibilities and limits of prospective GIS land cover 614 modelling - a compared case study: Garrotxes (France) and Alta Alpujarra Granadina (Spain). 615 International Journal of Geographical Information Science 19(6): 697-722 DOI

616 Pan Y, Birdsey RA., Fang J, Houghton R, Kauppi PE, Kurz WA, Oliver L, Shvidenko PA, Lewis 617 SL, Canadell JG, Ciais, P, Jackson RB, Pacala S, McGuire AD, Piao s, Rautiainen A, Sitch s, 618 Hayes D. 2011. A large and persistent carbon sink in the world's forests. Science, 1201609 DOI: 619 10.1126/science.1201609.

620 Parker D, Manson S, Jansen M, Hoffman M, Deadman P. 2003. Multi-Agent systems for the 621 simulation of land-Use and land-Cover change: a review. Annals of the American Association of 622 Geographers 93(2): 314-337 DOI https://doi.org/10.1111/1467-8306.9302004.

623 Pérez-Vega A, Mas JF, Ligmann-Zielinska A. 2012. Comparing two approaches to land use/cover 624 change modeling and their implications for the assessment of biodiversity loss in a deciduous 625 tropical forest. Environmental Modelling \& Software 29(1): 11-23 DOI 626 https://doi.org/10.1016/j.envsoft.2011.09.011.

627 Pérez-Vega A, Rocha Álvarez F, Regil García HH. 2016. Distribución espacial del uso/cubierta 628 del suelo y degradación forestal en la reserva de la biosfera Sierra Gorda de Guanajuato. Acta 629 Universitaria 26(2) DOI 10.15174/au.2016.1500. 
630 Peters EB, Wythers KR, Bradford JB, Reich PB. 2013. Influence of disturbance on temperate

631 forest productivity. Ecosystems 16(1):95-110 DOI https://doi.org/10.1007/s10021-012-9599-y.

632 Pijanowski BC, Brown DG, Shellito BA, Manik, GA. 2002. Using neural networks and GIS to 633 forecast land use changes: a land Transformation Model. Computers, Environment and Urban 634 Systems 26:553-575 DOI https://doi.org/10.1016/S0198-9715(01)00015-1.

635 Pompa M. 2008. Análisis de la deforestación en ecosistemas montañosos del noroeste de México. 636 Avances en Investigación Agropecuaria, 12(2).

637 Quan B, Römkens MJM, Li R, Wang F, Chen J. 2011. Effect of land use and land cover change 638 on soil erosion and the spatio-temporal variation in Liupan Mountain Region, southern Ningxia, 639 China. Frontiers of Environmental Science \& Engineering in China 5(4): 564-572 DOI 640 https://doi.org/10.1007/s11783-011-0348-9.

641 R Core Team. 2016. R: A language and environment forstatistical computing. Vienna: R 642 Foundation for Statistical Computing.

643 Rutherford GN, Bebi P, Edwards PJ, Zimmermann NE. 2008. Assessing land-use statistics to 644 model land cover change in a mountainous landscape in the European Alps. Ecological 645 modelling 212(3-4):460-471 DOI https://doi.org/10.1016/j.ecolmodel.2007.10.050.

646 Scheffer M, Carpenter S, Foley JA, Folke C, Walker B. 2001. Catastrophic shifts in 647 ecosystems. Nature 413(6856):591 DOI 10.1038/35098000

648 Shao Y, Lunetta RS. 2012. Comparison of support vector machine, neural network, and CART 649 algorithms for the land-cover classification using limited training data points. ISPRS Journal of 650 Photogrammetry and Remote $\quad$ Sensing 70:78-87 DOI 651 https://doi.org/10.1016/j.isprsjprs.2012.04.001.

652 Silva RS. 2009. Estudio Regional Forestal "Unidad de Manejo Forestal San Juanito A.C. 653 UMAFOR San Juanito A. C.

654 Soares-Filho B, Rodrigues H, Follador M. 2013. A hybrid analytical-heuristic method for 655 calibrating land-use change models. Environmental Modelling \& Software 43: 80-87 DOI 656 https://doi.org/10.1016/j.envsoft.2013.01.010.

657 Soares-Filho BS, Cerqueira GC, Pennachin CL, 2002. DINAMICA — a stochastic cellular 658 automata model designed to simulate the landscape dynamics in an Amazonian colonization 659 frontier. Ecological. Modelling 154: 217-235 DOI https://doi.org/10.1016/S0304-3800(02)000596605.

661 Soares-Filho BS, Ferreira BM, Filgueira DS; Rodrigues HO, Hissa LBV, Lima LS, Machado RF, 662 Costa WLS. Dinamica project. Remote Sensing Center. Federal University of Minas Gerais 663 (UFMG), Belo Horizonte, MG, Brazil. http://www.csr.ufmg.br/dinamica/. Accessed 24 Jul 2017.

664 Soares-Filho BS, Moutinhob P, Nepstadb D, Andersond A, Rodriguesa H, Garciaa R, 2010. Role 665 of Brazilian amozon protected areas in climate change mitigation. Proceedings of the National 666 Academy of the United States of America 107(24): 10821-10826; DOI: 667 https://doi.org/10.1073/pnas.0913048107

668 Soares-Filho BS, Nepstad DC, Curran LM, Cerqueira GC, Garcia RA, Ramos CA, Voll E, 669 Mcdonald A, Lefebvre P, Schlesinger, P. 2006. Modelling conservation in the Amazon 670 basin. Nature 440(7083):520 DOI https://doi.org/10.1038/nature04389. 
671 Soares-Filho BS, Rodrigues H, Costa, W. 2009. Modeling Environmental Dynamics with 672 Dinamica

673 Available at: http://www.lapa.ufscar.br/geotecnologias-1/Dinamica_EGO_guidebook.pdf

Ego.

674 Stan K D, Sanchez-Azofeifa A. 2017. The Edmonton-Calgary corridor: Simulating future land 675 cover change under potential government intervention. Land Use Policy 63:356-368 DOI 676 https://doi.org/10.1016/j.landusepol.2017.01.039.

677 Sun G, Zhou G, Zhang Z, Wei X, McNulty SG, Vose JM. 2006. Potential water yield reduction 678 due to forestation across China. Journal of Hydrology 328(3-4):548-558 DOI 679 https://doi.org/10.1016/j.jhydrol.2005.12.013.

680 Tambosi LR, Martensen AC, Ribeiro MC, Metzger JP. 2014. A framework to optimize 681 biodiversity restoration efforts based on habitat amount and landscape connectivity. Restoration 682 Ecology 22(2): 169-177 DOI https://doi.org/10.1111/rec.12049.

683 Teixeira AM, Soares-eFilho BS, Freitas S, Metzger JPW. 2009. Modeling landscape dynamics in 684 the Atlantic Rainforest domain: implications for conservation. Forest Ecology and Management 685 257:1219e1230 DOI 10.1016/j.foreco.2008.10.011.

686 Torrens PM. 2006. Geosimulation and its application to urban growth modeling. Springer-Verlag: 687 London, U. K.

688 United Nations (UN) 2015. Transforming our World: The 2030 Agenda for Sustainable 689 Development Available

690 https://sustainabledevelopment.un.org/content/documents/21252030\%20Agenda\%20for\%20Sust 691 ainable\%20Development\%20web.pdf

692 United States Geological Survey. Available at: http://glovis.usgs.gov.

693 Vázquez-Quintero G, Solís-Moreno R, Pompa-García M, Villarreal-Guerrero F, Pinedo-Alvarez 694 C, Pinedo-Alvarez A. 2016. Detection and projection of forest changes by using the Markov Chain 695 Model and cellular automata. Sustainability 8(3):236 DOI 10.3390/su8030236.

696 Velázquez A, Mas JF, Díaz Gallegos JR, Mayorga Saucedo R, Alcántara PC, Castro R, Fernández 697 T, Bocco G, Ezcurra E, Palacio JL. 2002. Patrones y tasas de cambio de uso del suelo en 698 México. Gaceta ecológica (62).

699 Weiskittel AR, Crookston NL, Radtke PJ. 2011. Linking climate, gross primary productivity, and 700 site index across forests of the western United States. Canadian Journal of Forest Research 41(8): 701 1710-1721 DOI https://doi.org/10.1139/x11-086.

702 Ximenes AC, Almeida CM, Amaral S, Escada MIS, Aguiar APD. 2011. Spatial dynamic 703 modelling of deforestation in the Amazon. In Cellular Automata-Simplicity Behind Complexity. 704 InTech DOI 10.5772/16137.

705 Yanai AM, Fearnside PM, de Alencastro Graça PML, Nogueira EM. 2012. Avoided deforestation 706 in Brazilian Amazonia: simulating the effect of the Juma Sustainable Development 707 Reserve. Forest Ecology and Management 282:78-91 DOI 708 https://doi.org/10.1016/j.foreco.2012.06.029. 
Table $\mathbf{1}$ (on next page)

Scenes characteristics 


\begin{tabular}{ccc}
\hline Sensor & Date & Characteristics \\
\hline Landsat TM 5 & 1990 & 7 spectral bands, 30 m resolution \\
Landsat TM 5 & 2005 & 7 spectral bands, 30 m resolution \\
Landsat OLI & 2017 & 8 spectral bands, 30 m resolution; 1 panchromatic band 15 \\
8 & & m resolution \\
\hline
\end{tabular}

$1 \mathrm{TM}=$ Thematic Mapper, OLI= Operational Land Imager

2 


\section{Table 2 (on next page)}

Land use/land cover types determined through the supervised classification method 


\begin{tabular}{ccc}
\hline Land use and land cover & Acronym & Description \\
\hline Primary forest & PF & Forest fully covered with canopy \\
Secondary forest & SF & Forest partially covered with canopy \\
Human settlements & HS & Residential areas \\
Areas without vegetation & AWV & Areas without vegetation, agriculture areas or induced \\
& grasslands \\
Water bodies & WB & Water bodies \\
\hline
\end{tabular}

1 
Table 3 (on next page)

Variables feeding the deforestation model 


\begin{tabular}{|c|c|c|c|c|}
\hline No & Variable type & Name & Unit & Acronym \\
\hline 1 & & Density of main roads & $\mathrm{m}^{2} / \mathrm{Km}^{2}$ & Denmr \\
\hline 2 & & Density of secondary roads & $\mathrm{m}^{2} / \mathrm{Km}^{2}$ & Densr \\
\hline 3 & Density & Density of main streams & $\mathrm{m}^{2} / \mathrm{Km}^{2}$ & Denms \\
\hline 4 & & Density of secondary streams & $\mathrm{m}^{2} / \mathrm{Km}^{2}$ & Denss \\
\hline 5 & & Density of rural settlements & $\mathrm{m}^{2} / \mathrm{Km}^{2}$ & Denrs \\
\hline 6 & & Distance to sawmills & $\mathrm{m}$ & Diss \\
\hline 7 & & Distance to water bodies & $\mathrm{m}$ & Diswb \\
\hline 8 & & Distance to main roads & $\mathrm{m}$ & Dismr \\
\hline 9 & & Distance to secondary roads & $\mathrm{m}$ & Dissr \\
\hline 10 & & Distance to main streams & $\mathrm{m}$ & Disms \\
\hline 11 & Proximity & Distance to secondary streams & $\mathrm{m}$ & Disss \\
\hline 12 & & Distance to rural settlements & $\mathrm{m}$ & Disrs \\
\hline 13 & & Distance to urban settlements & $\mathrm{m}$ & Disus \\
\hline 14 & & Distance to mines & $\mathrm{m}$ & Dism \\
\hline 15 & & $\begin{array}{l}\text { Distance to areas without apparent } \\
\text { vegetation }\end{array}$ & $\mathrm{m}$ & Disawav \\
\hline 17 & & Altitude & $\mathrm{m}$ & Alt \\
\hline 18 & Topographic & Slope & $\circ$ & Slop \\
\hline 19 & & Topographic position index & Dimensionless & TPI \\
\hline
\end{tabular}

1 


\section{Table 4(on next page)}

Transitions of land use/land cover 


\begin{tabular}{|c|c|c|c|c|c|c|}
\hline \multicolumn{7}{|c|}{ To } \\
\hline \multirow{6}{*}{ 总 } & & $\mathrm{PF}$ & SF & $\mathrm{HS}$ & AWV & WB \\
\hline & PF & & $\checkmark$ & $\checkmark$ & $\checkmark$ & \\
\hline & SF & & & & $\checkmark$ & \\
\hline & HS & & & & & \\
\hline & AWV & & & & & \\
\hline & WB & & & & & \\
\hline
\end{tabular}

1 


\section{Table 5 (on next page)}

Area occupied for five types of land uses during 1990, 2005 and 2017, and rate of change for the periods 1990-2005 and 2005-2017. 


\begin{tabular}{|c|c|c|c|c|c|c|c|c|}
\hline \multirow{2}{*}{ Land Use } & \multicolumn{3}{|c|}{ Occupied area (Ha) } & \multicolumn{3}{|c|}{ Occupied area $(\%)$} & \multicolumn{2}{|c|}{$\begin{array}{l}\text { Rate of } \\
\text { change }\end{array}$} \\
\hline & 1990 & 2005 & 2017 & 1990 & 2005 & 2017 & $\begin{array}{l}1990- \\
2005\end{array}$ & $\begin{array}{l}2005- \\
2017\end{array}$ \\
\hline AWV & 20444.18 & 23828.59 & 24101.92 & 4.11 & 4.79 & 4.85 & 8.33 & 8.43 \\
\hline $\mathrm{SF}$ & 199121.38 & 223948.16 & 286922.04 & 40.05 & 45.05 & 57.72 & 8.03 & 10.68 \\
\hline HS & 154.60 & 272.35 & 521.65 & 0.03 & 0.05 & 0.10 & 12.58 & 15.96 \\
\hline WB & 26.9712 & 103.76 & 153.91 & 0.01 & 0.02 & 0.03 & 27.48 & 12.36 \\
\hline $\mathrm{PF}$ & 277380.46 & 248973.97 & 185427.79 & 55.80 & 50.08 & 37.30 & 6.41 & 6.21 \\
\hline
\end{tabular}

$1 \mathrm{AWV}=$ Areas without vegetation, $\mathrm{SF}=$ Secondary forest, $\mathrm{HS}=$ Human settlements, $\mathrm{WB}=$ Water bodies, $\mathrm{PF}=$ Primary 2 forest. 


\section{Table 6 (on next page)}

Land use/land cover change dynamics 


\begin{tabular}{ccccccc}
\hline Land use & $\begin{array}{c}\text { Difference } \\
\mathbf{1 9 9 0 - 2 0 0 5}(\mathbf{h a})\end{array}$ & $\begin{array}{c}\text { Difference } \\
\mathbf{2 0 0 5 - 2 0 1 7 ( h a )}\end{array}$ & $\begin{array}{c}\text { Overall } \\
\text { Difference (ha) }\end{array}$ & $\begin{array}{c}\text { Type of } \\
\text { change }\end{array}$ & 1990-2005 (ha) & 2005-2017 (ha) \\
\hline AWV & 3384.40 & 273.34 & 3657.74 & Deforestation & 3120.40 & 7283.95 \\
SF & 24826.78 & 62973.88 & 87800.66 & Degradation & 54455.78 & 73904.27 \\
HS & 117.74 & 249.31 & 367.05 & Other & 76.22 & 219.41 \\
WB & 76.79 & 50.15 & 126.94 & Recovery & 27128.71 & 20204.13 \\
PF & -28406.49 & -63546.18 & -91952.66 & -- & -- & -
\end{tabular}

$1 \mathrm{AWV}=$ Areas without vegetation, $\mathrm{SF}=$ Secondary forest, $\mathrm{HS}=$ Human settlements, $\mathrm{WB}=$ Water bodies, $\mathrm{PF}=$ Primary 2 forest.

3 
Table 7 (on next page)

Transition matrix of probability for land use/land cover change (1990-2005, 2005-2017, 1990-2017) 


\begin{tabular}{ccccccc}
\hline & Periodo & AWV & PF & HS & WB & PF \\
\hline \multirow{3}{*}{ AWV } & $1990-2005$ & $\mathbf{0 . 9 0 0 0}$ & 0.0250 & 0.0250 & 0.0250 & 0.0250 \\
& $2005-2017$ & $\mathbf{0 . 6 2 5 0}$ & 0.3504 & 0.0108 & 0.0029 & 0.0109 \\
& $1990-2017$ & $\mathbf{0 . 6 6 1 5}$ & 0.3124 & 0.0120 & 0.0035 & 0.0106 \\
\cline { 2 - 7 } SF & $1990-2005$ & 0.0222 & $\mathbf{0 . 7 5 1 6}$ & 0.0008 & 0.0005 & 0.2248 \\
& $2005-2017$ & 0.0557 & $\mathbf{0 . 8 1 1 6}$ & 0.0004 & 0.0000 & 0.1323 \\
& $1990-2017$ & 0.0654 & $\mathbf{0 . 7 9 4 5}$ & 0.0012 & 0.0006 & 0.1384 \\
\cline { 2 - 8 } HS & $1990-2005$ & 0.0452 & 0.0645 & $\mathbf{0 . 8 8 0 6}$ & 0.0000 & 0.0097 \\
& $2005-2017$ & 0.0557 & 0.2479 & $\mathbf{0 . 6 9 5 9}$ & 0.0000 & 0.0004 \\
& $1990-2017$ & 0.0651 & 0.0774 & $\mathbf{0 . 8 5 7 5}$ & 0.0000 & 0.0000 \\
\hline \multirow{3}{*}{ WB } & $1990-2005$ & 0.0000 & 0.1254 & 0.0000 & $\mathbf{0 . 8 5 5 3}$ & 0.0193 \\
& $2005-2017$ & 0.0095 & 0.1684 & 0.0000 & $\mathbf{0 . 8 0 3 0}$ & 0.0191 \\
& $1990-2017$ & 0.0000 & 0.1868 & 0.0000 & $\mathbf{0 . 7 9 5 7}$ & 0.0175 \\
\hline \multirow{3}{*}{ PF } & $1990-2005$ & 0.0020 & 0.2865 & 0.0000 & 0.0000 & $\mathbf{0 . 7 1 1 5}$ \\
& $2005-2017$ & 0.0056 & 0.3798 & 0.0003 & 0.0000 & $\mathbf{0 . 6 1 4 4}$ \\
& $1990-2017$ & 0.0071 & 0.4419 & 0.0002 & 0.0000 & $\mathbf{0 . 5 5 0 8}$ \\
\hline
\end{tabular}

$1 \mathrm{AWV}=$ Areas without vegetation, $\mathrm{SF}=$ Secondary forest, $\mathrm{HS}=$ Human settlements, $\mathrm{WB}=$ Water bodies, $\mathrm{PF}=$ Primary 2 forest. 
Table 8(on next page)

Percentage of surface area occupied by five land use/land cover types and rate of change for 2017-2050 based on three scenarios 


\begin{tabular}{cccccccc}
\hline \multirow{2}{*}{ Land Use } & \multicolumn{3}{c}{ Occupied surface area (\%) } & \multicolumn{5}{c}{ Change rate } \\
\cline { 2 - 8 } & $\mathbf{2 0 1 7}$ & $\mathbf{2 0 5 0 s}$ & $\mathbf{2 0 5 0 0}$ & $\mathbf{2 0 5 0 p}$ & $\mathbf{2 0 1 7 - 2 0 5 0 s}$ & $\mathbf{2 0 1 7 - 2 0 5 0 0}$ & $\mathbf{2 0 1 7 - 2 0 5 0 p}$ \\
\hline AWV & 4.848 & 5.275 & 5.017 & 7.695 & 3.40 & 3.23 & 4.96 \\
SF & 57.716 & 73.721 & 61.863 & 83.628 & 3.99 & 3.35 & 4.53 \\
HS & 0.105 & 0.105 & 0.105 & 0.105 & 3.13 & 3.13 & 3.13 \\
WB & 0.031 & 0.031 & 0.031 & 0.031 & 3.12 & 3.13 & 3.12 \\
PF & 37.300 & 20.868 & 32.983 & 8.541 & 1.75 & 2.76 & 0.72 \\
\hline
\end{tabular}

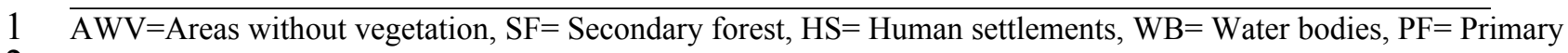
2 forest, $\mathrm{S}=$ Stationary, $\mathrm{O}=$ Optimistic, $\mathrm{P}=$ Pessimistic.

3 
Table 9 (on next page)

Land use/land cover change dynamics (ha) under three proyected scenario. 


\begin{tabular}{cccc}
\hline Land use & $\mathbf{2 0 1 7 - 2 0 5 0}_{\mathbf{s}}$ & $\mathbf{2 0 1 7 - 2 0 5 0}_{\mathbf{0}}$ & $\mathbf{2 0 1 7 - 2 0 5 0}_{\mathbf{p}}$ \\
\hline AWV & 2121.97 & 840.44 & 14150.28 \\
SF & 79565.57 & 20617.02 & 128818.00 \\
HS & 0.87 & 1.25 & 1.05 \\
WB & 0.46 & 0.32 & 0.10 \\
PF & -81688.00 & -21459.04 & -142969.31 \\
\hline
\end{tabular}

$1 \mathrm{AWV}=$ Areas without vegetation, $\mathrm{SF}=\mathrm{Secondary}$ forest, $\mathrm{HS}=$ Human settlements, $\mathrm{WB}=$ Water bodies, $\mathrm{PF}=$ Primary 2 forest, $\mathrm{S}=$ Stationary, $\mathrm{O}=$ Optimistic, $\mathrm{P}=$ Pessimistic.

3 
Figure 1

Location and elevations of the study area

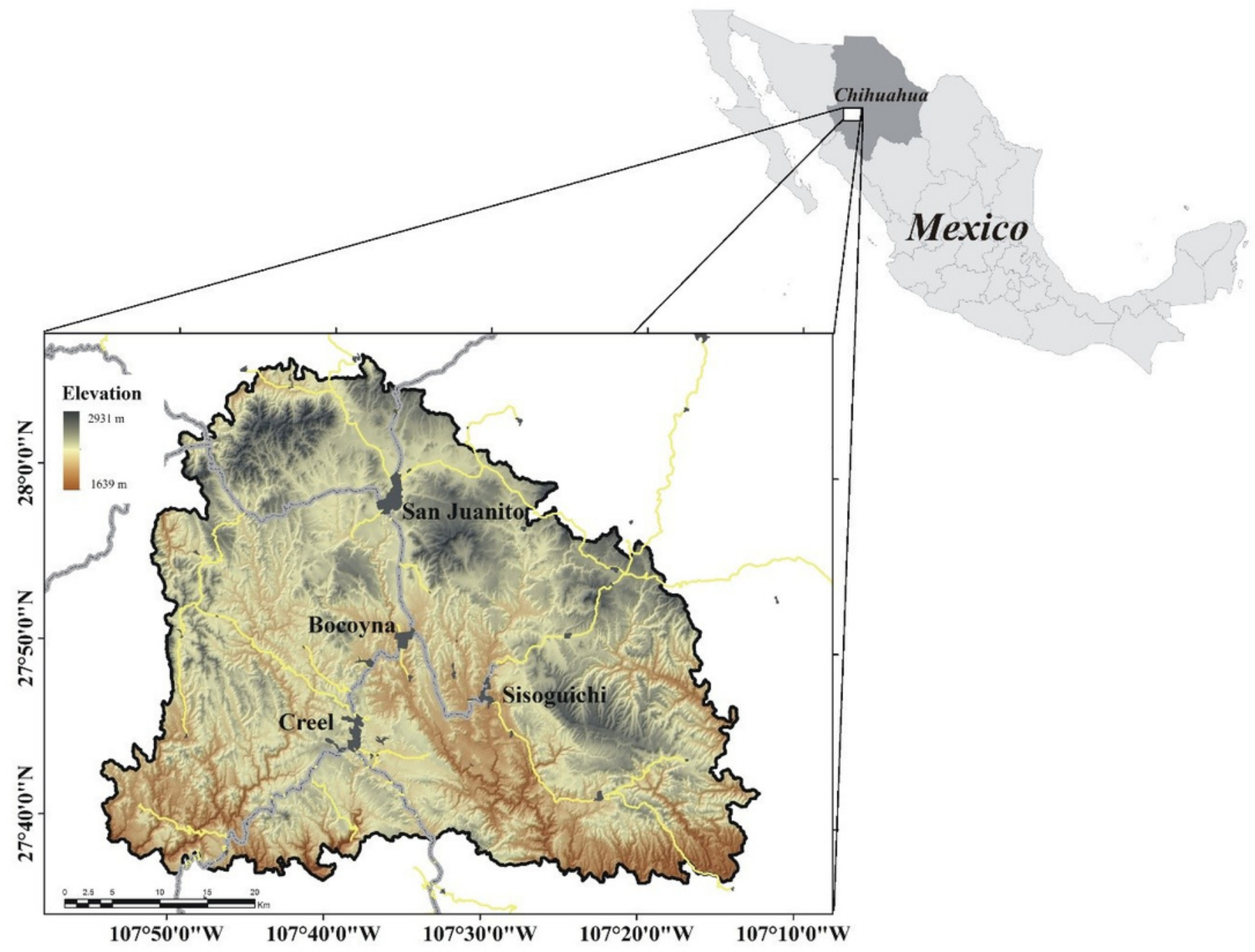


Figure 2

Flowchart of the methodological procedure followed to produce the proposed scenarios. Abbreviations: TM: Tematic Mapper, OLI: Operational Land Imager, WoE: Weights of Evidence, LUCC: Land use and cover change

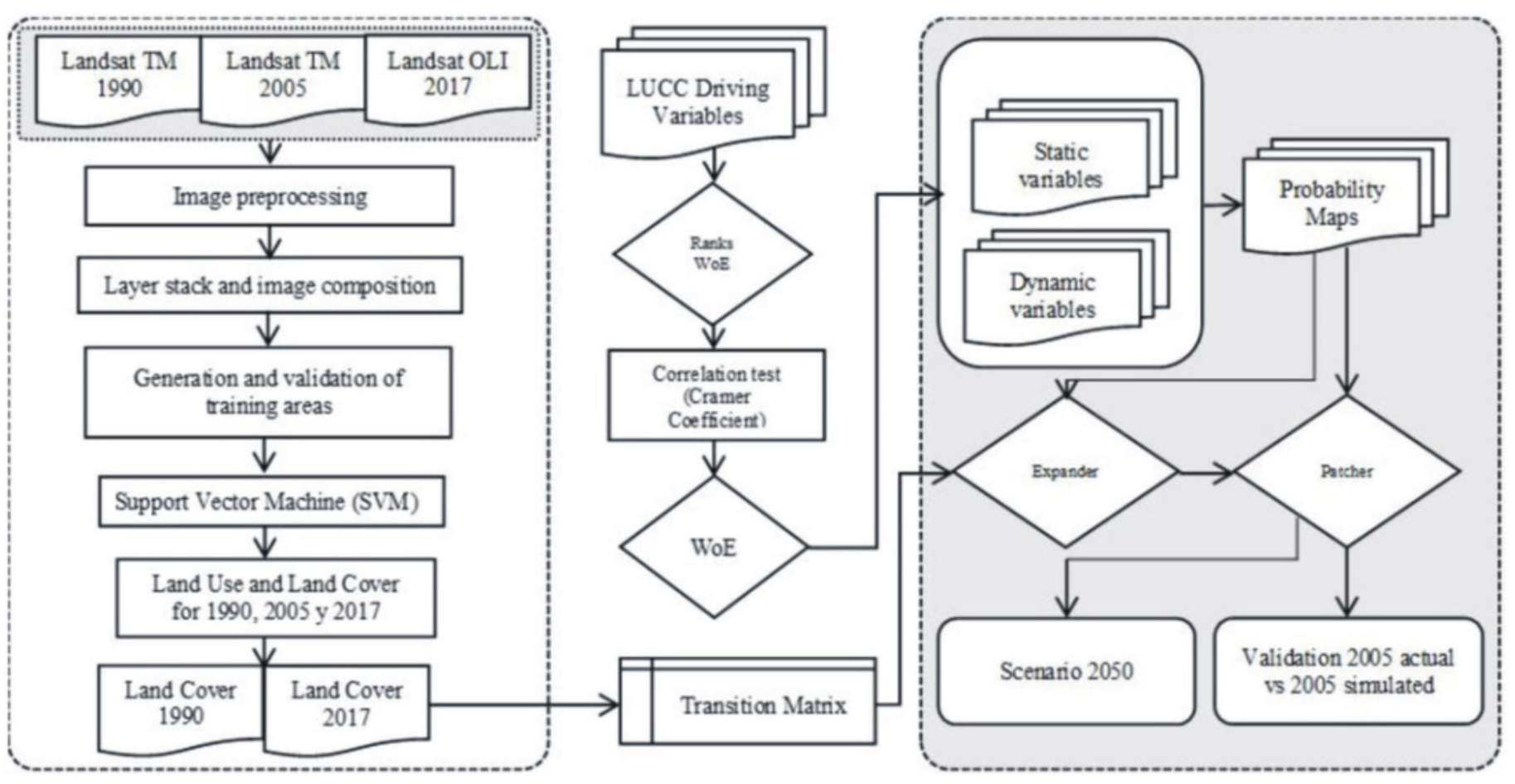




\section{Figure 3}

Land use/land cover of 1990 (a), 2005 (b), 2017 (c), changes during 1990-2005 (d) and changes during 2005-2017. Abbreviations: AWV: areas without vegetation, SF: secondary forest, WB: water bodies, HS: human settlements and PF: primary forest.

a)

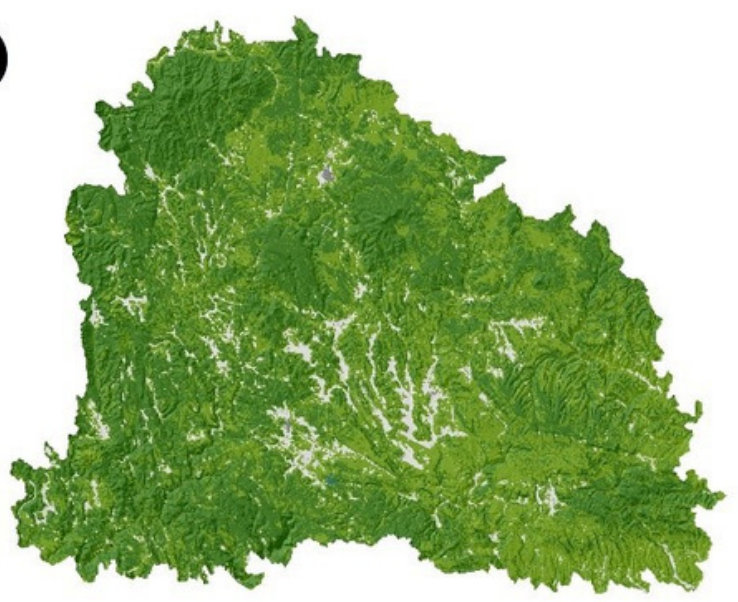

c)

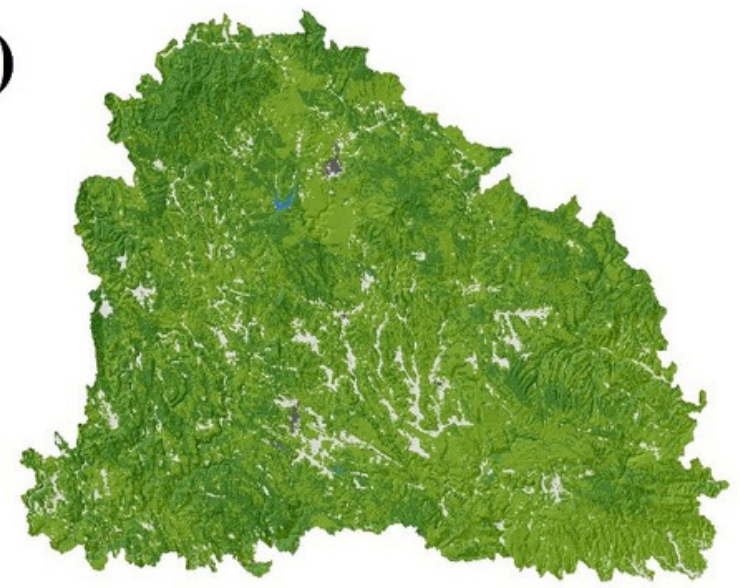

e)

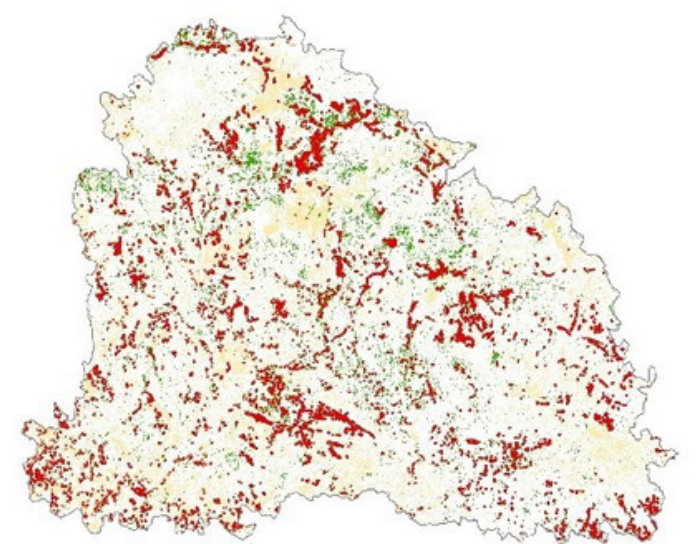

PeerJ reviewing PDF | (2018:09:31400:2:1:NEW 30 Jan 2019) b)

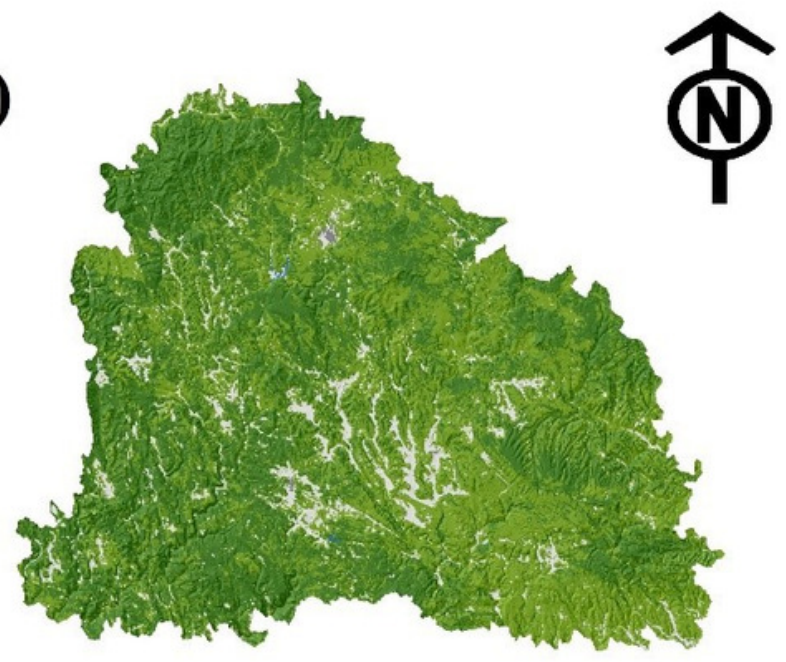

d)

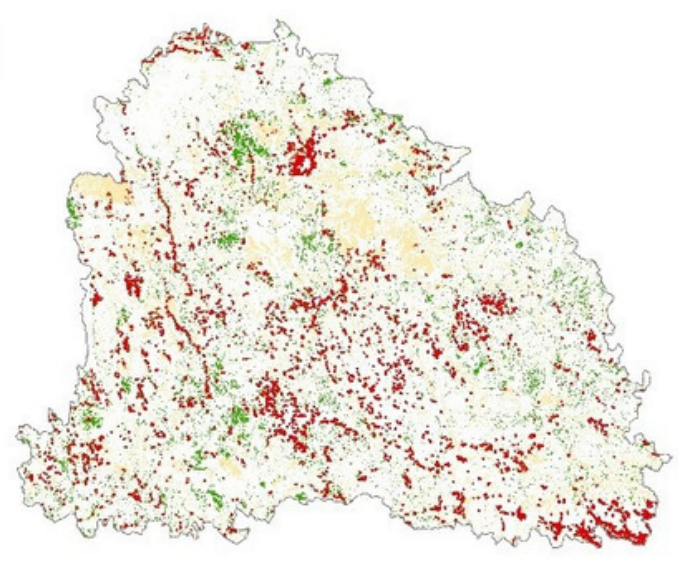

Land Use Land Cover

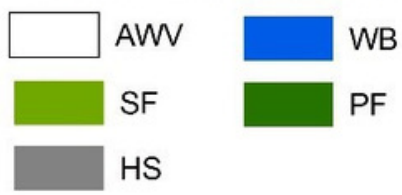

Changes

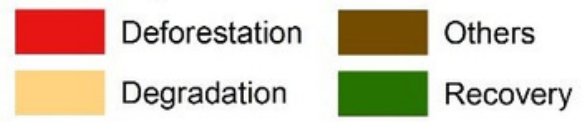


Figure 4

Variation of the FSI as a function of different distance

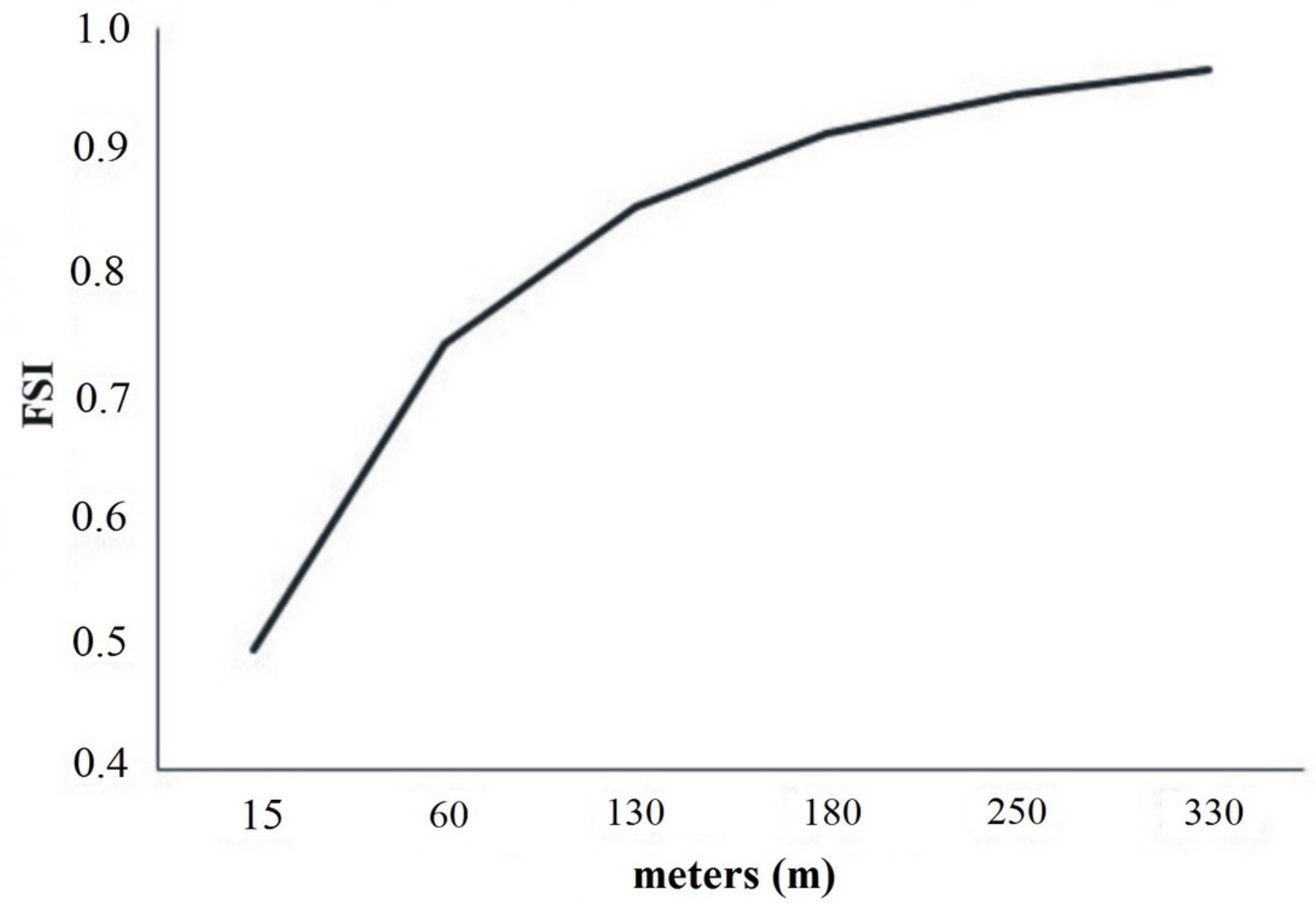




\section{Figure 5}

a) Land use/land cover of 2017 and simulated land use/land cover projected for the year 2050 as a result of the b) Stationary, c) Pessimistic and d) Optimistic scenarios. Abbreviations: AWV: areas without vegetation, SF: secondary forest, WB: water bodies

a)

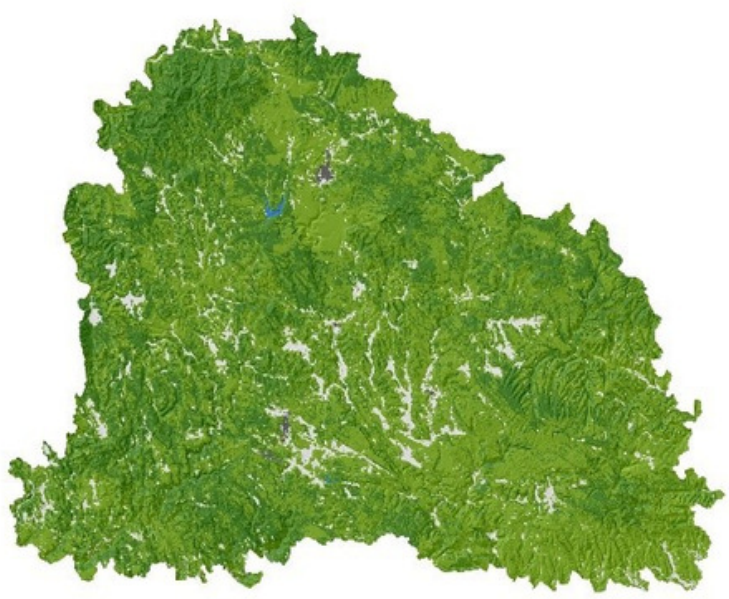

c)

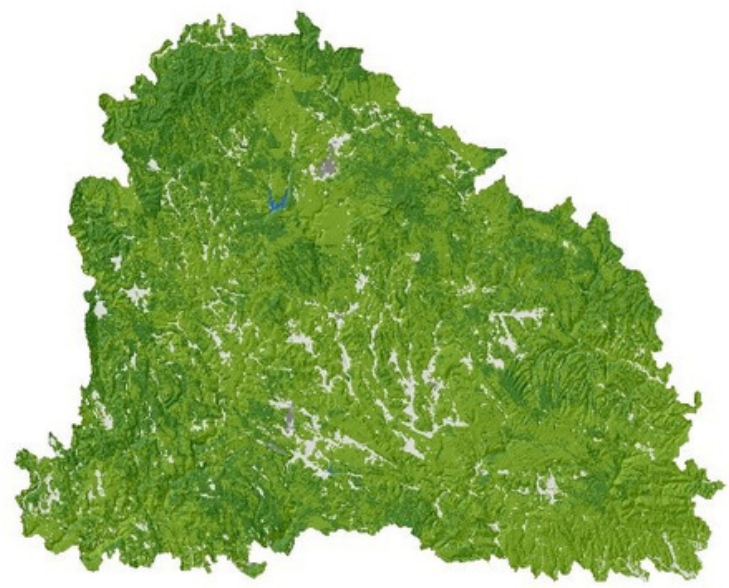

Land Use Land Cover

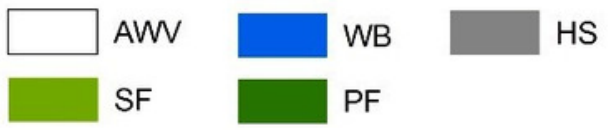

b)

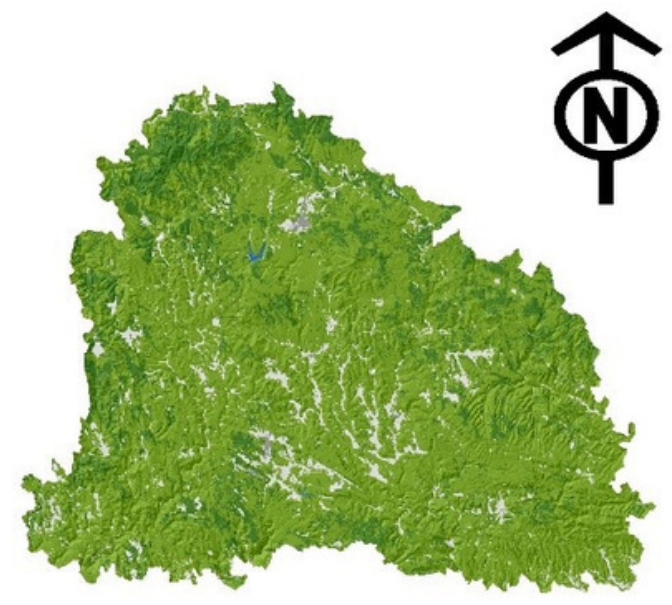

d)
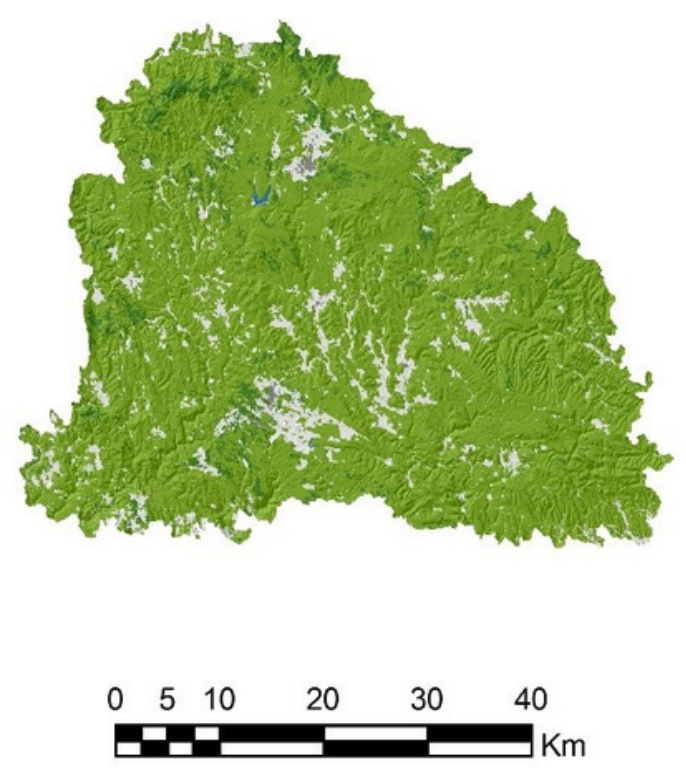